\title{
Land, group identities and competing justice values in South Africa: Reformed perspectives on embracive justice and permeable identity formation
}

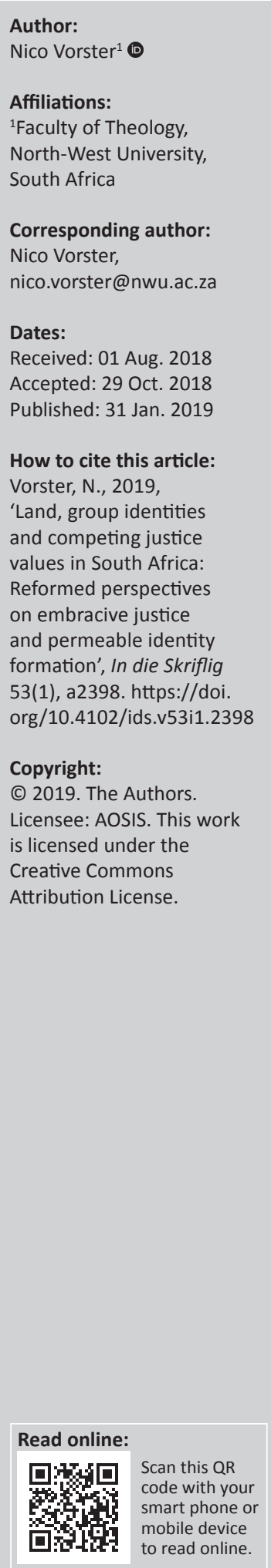

This contribution argues that competing justice values are hindering progress in the land debate in South Africa. Two factors contribute to this state of affairs: Firstly, social justice is a multifaceted concept undergirded by a range of values. These values often stand in tension with each other, especially when it comes to intergenerational conflicts and transitional social contexts. Secondly, South African approaches to justice seem to be closely related to group identities, particular historical experiences and political interests. To address the impasse on land, we need to recalibrate our disposition to the hierarchy of justice values and the priority we assign to each value. Moreover, we need to address the relationship between justice dispositions and identities. The question posed is the following: Can reformed-theological resources add an extra ingredient to our understanding of social justice? What would be the implications of such a recalibration for our understanding of human identity? This article proposes the concept of embracing justice as orienting principle in resolving the land issue. Furthermore, it draws on reformed notions of self-denial and cross-bearing to advocate a permeable notion of identity that internalises and enacts the demands of embracive justice.

\section{Introduction and background}

Nearly a decade ago James Gibson identified the land question as having the potential to ignite the South African political landscape:

Land is a tinderbox issue, with just a few well-placed sparks, a serious conflagaration could ignite in South African politics. (Gibson 2009:85)

Today the words of Gibson sound almost clairvoyant. The 54th National Elective Conference of the African National Congress (ANC) held at NASREC in December 2017 and the subsequent debate on expropriation without compensation provides a vivid and disturbing illustration of the underlying tensions, disagreements and frustrations that exist among various groups in South Africa about land redistribution. Tragically and almost ironically, it seems as if the complexity of the South African political and socio-economic landscape crystalises in the land question. Land is, and perhaps always was, the site of struggle in South Africa where different understandings of history, diverse group identities, competing rights and value systems, and diverging theories of justice come to a head (see Gibson 2009:2-3).

Three pieces of discriminatory land legislation, promulgated in the 20th century, have shaped the contemporary South African landscape decisively. The Native Land Act (No 27 of 1913), which was enacted a few years after the formation of the South African Union in 1910, declared about 7\% of South African land as 'Black reserves' or 'traditional areas'. The Native Trust and Land Act of 1936 extended the reserves to about $13 \%$ of South African land, but also tightened the control of government of all black economic pursuits, including agricultural activities (Van der Elst 2017:959). Black people living in so-called 'Black spots' outside reserve areas were forced to relocate to the reserves and were prohibited from buying or selling land outside of the reserves (Gibson 2009:11; Van der Elst 2017:959). The inhabitants of the reserves only had 'conditional use rights' under trusteeship of the State (Mothlanthe 2017:303). As far as urban areas were concerned, Section 5 of the Black Administration Act and the notorious Group Areas Act of 1950 consigned racial groups to particular residential and commercial spaces and legitimised forced removals. A whole range of other laws were promulgated by the Apartheid government to regulate land ownership and to control the influx of black workers to cities. The end result was the development of a 'highly dualistic and racially segregated' land structure with a commercial and technological advanced white commercial farming sector on the one hand, and an underdeveloped black peasant sector on the other (Cousins \& Scoones 2010:32). 
From a moral point of view, it is clear that the colonial and Apartheid governments committed acts that defy the basic essence of social justice. The pieces of legislation were not designed to distribute land equitably, but to ensure that white people own the vast majority of productive agricultural land. Black people were arbitrarily deprived of land, property and livelihoods, and relocated against their will. Native reserves and homelands remained overcrowded, the land allocated was unproductive and the infrastructure remained poorly developed. This inevitably caused a systemic chain reaction of gradual black impoverishment (Van der Elst 2017:959). President Ramaphosa aptly described the land issue as a burden of history, an 'original sin' that the present generation has to resolve (see Merten 2018:3).

Since 1994, little progress has been made to address the historical injustices of land dispossession and to enforce the constitutional ideals of land restitution and redistribution. The initial target was to redistribute $30 \%$ or 24.6 million hectares of white-owned agricultural land by 1999 through 'grants-based redistribution and a rights-based restitution programme' (O'Laughlin et al. 2013:8). By March 2011 only $7.2 \%$ of land had been transferred. The initial target of 30\% had to be extended to 2025 (O'Laughlin et al. 2013:8). Some argue that the Constitution of South Africa (hereafter 'the Constitution') (South Africa 1996) itself contributes to the slow pace of land reform by requiring fair compensation for land that is expropriated (see Choruma 2017:33), while others blame a lack of political will, inadequate budgeting, poor implementation and dysfunctional structures (Mothlanthe 2017:215, 233). ${ }^{1}$ Be this as it may, land restitution and redistribution processes have proven to be extraordinarily slow and cumbersome despite various policies and strategies being introduced since 1999 (Mothlanthe 2017:208). About 4.3 million hectares of land, acquired for land reform purposes, are currently 'out of production' (Mothlanthe 2017:257); various farms have been bought by the State for land redistribution ends, but they have not been transferred to beneficiaries; a small number of restitution claims have been settled; and no 'substantial' legislation exists that protects land tenure in former homelands (Mothlanthe 2017:233, 257). The result of this situation has been increasing social conflict as can be seen from the fact that illegal land invasions have become a regular phenomenon.

The fundamental justice issue underlying the land question is: How can groups who were affected by historical patterns of land discrimination and land deprivation be properly compensated for their loss and how can greater forms of social equality be achieved? At the core of the question stands the highly complex, multi-layered concept of justice which is undergirded by different sets of criteria and values (see Gibson 2009:3). Procedural justice principles, for instance, give priority to fair justice processes; distributive justice to a just allocation of social goods between diverse members of society; commutative justice to fair transactional exchanges between members of society; redistributive justice period between 1994 and 2017 (Mothlanthe 2017:2015). to equal dignity, redress and equality of outcome; restorative justice to restitution, rehabilitation and reconciliation, and retributive justice to desert; and proportional punishment for crimes committed. Although these social justice values do not necessarily invalidate each other, they often stand in a dialectical relationship with each other. Redistributive justice values such as redress, for example, often enters into conflict with typical procedural justice principles such as impartiality and non-discrimination. This necessitates deliberation on the logical priority that ought to be given to the respective values.

The state of affairs becomes even more complicated when we bear in mind that notions of social justice vary among groups of people and are often closely intertwined with shared identities, particular historical experiences and immediate political interests. Gibson's survey (2009:117) provides ample evidence that members of groups who were historically exposed to systematic forms of discrimination or victimisation and find their solidarity in a shared sense of being wronged, tend to support public policies informed by redistributive justice values. Groups who have vested interests in the status quo are inclined to disparage policies that revisit the past and prefer justice values related to non-discrimination and due process. Group identities indeed 'structure the ways in which people view the issue' (Gibson 2009:92). The state of affairs is not surprising, as South African politics have historically been marked by the allocation of social costs and benefits along racial group lines (Gibson 2009:91). In a society where race and ethnic characteristics historically determined where persons can live and work, and what type of social benefits they could access, we can expect land issues to invigorate emotions around group membership.

\section{Competing justice values in the land debate}

Section 25 of the Constitution (South Africa 1996) provides a clear example of the competing justice values at stake in the South African context. On the one hand, it is characterised by a strong commitment to redistributive justice, but when it comes to the scale of justice values, redistributive aspirations seem to be curbed by procedural and commutative justice principles that safeguard individual property rights (subsections 1-3), prohibit the arbitrary deprivation of property (subsections 1 and 2) and ensure 'just and equitable' compensation to land owners affected by expropriation (subsection 3). Sound and fair procedures are obviously important to social justice, but some observers are critical of the manner in which the Constitution (South Africa 1996) employs these justice principles to resolve land issues. Section 25 , for instance, requires that compensation should be 'just and equitable'. However, it is not clear what equitable means. Does it require a willing seller-buyer agreement or market price compensation (see Mothlanthe 2017:221)? Another criticism levelled is that the Constitution's application (South Africa 1996) of procedural and commutative social justice principles often slows down land reform (see Van der Elst 2017:963). In fact, Gibson (2009:115) claims that some 
groups misuse constitutional instruments to resist land distribution and to perpetuate past inequities. At times, it seems as if the Constitution's emphasis (South Africa 1996) on extensive legal and judicial oversight apparatus are counterproductive when it comes to land restitution. The post-Apartheid South African state simply does not have the capacity to establish all of the oversight mechanisms required by the Constitution (South Africa 1996). Clear examples are the constitutionally established structures of the Land Claims Commission and Land Claims Court which have proven to be dysfunctional and inefficient. Consequently, some argue that we find ourselves in a situation where the means of justice actually defeats the ends of justice.

Admittedly, the priority that the Constitution (South Africa 1996) assigns to various justice values are, by no means, clear-cut. Some would argue that the Constitution (South Africa 1996) favours redistributive justice considerations above other justice values. The preamble to the Constitution (South Africa 1996 - section 1a), for instance, describes the achievement of equality as a key objective and value of the Constitution, while section 9 certainly holds to a substantive outcome-based equality, rather than the formal equal opportunities approach so evident in distributive justice approaches. Significantly, the Constitution (South Africa 1996) refers to past forms of 'unfair discrimination' and allows legislative measures to redress entrenched forms of inequity. Section 25(4) probably contains the strongest transformative impulse found in the Constitution (South Africa 1996) by allowing land to be expropriated 'in the public interest'. It also requires of the State to use legislative and other means to ensure equitable access to land. Section 25(5), moreover, protects the right to tenure of individuals or communities who de facto own property, but have no registered rights due to past discriminatory legislation. Sections 25(6 and 7) dictate the compensation of persons or communities who have been dispossessed after 1913, while section 25(8) allows the State to take legislative measures to enact land and water reforms. Such measures have to comply with the limitation clause of section 36(1) of the Constitution (South Africa 1996) that protects basic rule of law principles by requiring good reasons for limiting a right (see Pienaar 2015:11). Broadly speaking then, we can safely state that the property clause has a strong redistributive thrust (see Pienaar 2015:10), although the means of achieving equal outcomes are subject to typical procedural and commutative justice principles such as equal treatment, due process, fair compensation and impartial judicial oversight.

Redistributive justice reasoning certainly addresses the issue of historical injustices more emphatically than other paradigms of justice; yet, history teaches us that assigning priority to redistributive justice values in the hierarchy of justice values often prove to be a hazardous endeavour. States that exhibit a strong commitment to redress and redistribution often fall into the trap of abusing power and enacting oppressive forms of reverse discrimination. Redistribution also tends to create opportunities for corruption. These tendencies can certainly be observed in the land reform process in South Africa. Various redistribution projects in South Africa have been characterised by disturbing trends of elite capture. The High Level Panel Report (Mothlanthe 2017), the studies of Beinart, Delius and Hay (2017) and the findings of Kepe and Hall (2018) are united in expressing concern that the land reform process is currently being captured by corporate elites, chiefs and traditional leaders who endanger the tenure security of vulnerable people. According to the High Level Panel Report (Mothlanthe 2017:203), 'the problem is especially acute' in former homeland areas and in areas administered by the Ingonyama Trust where traditional leaders and officials often claim to have the sole right to sign agreements with 'investors in respect of communal land'. The problem is exacerbated by the lack of existing legislation to protect the tenure security of vulnerable people in the former homelands (Mothlanthe 2017:266).

Kepe and Hall (2018) make a similar alarming observation with regard to the Pro-Active Land Acquisition Strategy (PLAS):

Land reform increasingly take place through strategic partnership and other institutional forms that prevent Black people from getting and controlling land themselves. Instead the State is the 'willing buyer' which is buying up land at market price and retaining ownership, allocating use rights or leaseholds, often to white-owned companies or multi-nationals, while signing up farm workers as 'beneficiaries'. (p. 133)

So far, we have discussed the tension between procedural, commutative and redistributive social justice discourse in South Africa. However, retributive understandings of justice, characterised by a sense of due desert and proportional punishment for past crimes committed, are gaining significant public support. Gibson's survey (2009) already observed that retributive approaches to land justice are widely held in South African society. According to the survey (Gibson 2009:31), $85 \%$ of black respondents maintained that the white people took land illegitimately and therefore 'have no right to land today', while only $8 \%$ of whites people held the same view. Two thirds of the black respondents agreed that 'land must be returned to Blacks in South Africa, no matter what the consequences are for current owners and for political stability in South Africa'. Gibson (2009:156) also found that retributive attitudes are encountered mostly among those who identify strongly with a particular language or ethnic group.

The momentum of the retributive approach in the last decade is clearly due to the rise of populist political groups such as the Economic Freedom Front and the pro-Zuma faction within the ANC who insist that the Constitution (South Africa 1996) should be changed to make possible large-scale land expropriation without compensation. The ethical argument underlying the retributive land reform argument is that land was 'appropriated' under colonialism and Apartheid from Africans without compensation (see Choruma 2017:33). Because current land owners have profited unjustly from past 
discriminatory practices, the state can neither be expected to use market mechanisms to adjudicate current values of land nor can they compensate landowners for land illegitimately obtained (see Atuahene 2011:124; Gibson 2009:40). Ntebeza (quoted in Gibson 2009:31) goes as far as stating that private land should be confiscated by the State and redistributed for the sake of the public good.

However, serious moral questions arise. Firstly, the retributive notion of justice, propagated by some stakeholders in the South African land discourse, seems to separate individual accountability from moral agency. In essence, it argues that contemporary generations can be considered culpable for actions they themselves did not commit and, secondly, they can be held to account for the actions of others by being subjected to penalties such as land expropriation without compensation. But is this kind of logic not vindictive at its core? Surely person A cannot be punished for the actions of person $\mathrm{B}$, and if person $\mathrm{A}$ indirectly benefited from past illegal actions by person B, we as a society cannot expect him or her to carry the full burden of the historical injustices, especially because past colonial land grabs were committed by a state. Should land owners carry the burden alone? Does society not have the duty to spread the costs of the burden of history (see Vorster 2006:701)? Moreover, do we not enter the realm of naked power abuse when a legal system starts to separate accountability from moral agency and begins to claim for itself the right to attribute culpability to citizens irrespective of their own actions, simply on the basis of their lineage, background or group association.

Opponents of the retributive argument claim that land reform can be implemented through less drastic constitutional measures that are non-vindictive and compatible with the values of an open and free democratic society: The High Level Panel Report, compiled by former acting president Kgalema Mothlanthe (2017) and a panel of experts, for instance, considers calls for the expropriation of land without compensation as ill-advised, because:

government has not used the powers it already has to expropriate land for land reform purposes effectively, nor used the provisions in the Constitution that allow compensation to below market value in particular circumstances. Rather than recommend that the Constitution be changed, the Panel recommends that government should use its expropriation powers more boldly, in ways that test the meaning of the compensation provisions in section 25(3), particularly in relation to land that is unutilized or under-utilized. (p. 51)

Another problematic feature of retributive approaches to the land debate is that vindictive actions may have consequences for innocent third parties. Recent figures of the Department Agriculture, Forestry and Fisheries indicate that the agricultural sector owes banks over R144 billion. This inevitably leads to questions about the duty of the state and the rights of third parties who are also affected by retributive measures such as expropriation without compensation (Mahlaka 2018:3).
From the preceding discussion, we can deduce that fairness and justice matters in the land debate, but that procedural, commutative, redistributive and retributive understandings of justice seem to be at variance. We can also safely agree with Gibson (2009:92) that group dynamics and the psychological benefits attached to group membership play a major role in justice positions taken on land reform. The challenging question is how to apply theories of social justice within a transitional political context marked by deep-seated racial, social and political divisions. How do we address the problem of social groupings making competing justice claims and assigning different priorities to classical justice values?

\section{Reformed perspectives on embrace and permeable identity}

In his highly influential book titled Exclusion and embrace, Miroslav Volf (1996) connects justice and embrace with each other:

To agree on justice in conflict situations you must want more than justice, you must want embrace. There can be no justice without the will to embrace. It is however equally true that there can be no genuine and lasting embrace without justice. (p. 216)

Building on Volf's argument, I argue that to de-escalate the land conflict in South Africa, we have to explore the concept of embracive justice as orienting principle in the hierarchy of justice values. Distributive, redistributive, retributive, procedural and commutative concepts of justice are always relevant to any justice debate, but we have to accept that they may not be equipped to act as orienting principles in the extraordinary transitional context of South Africa. Secondly, I argue that the enactment of embracive justice requires permeable identities. By permeable identity, I mean identities that are open to self-correction, willing to accept inconvenient truths, embracive of the other and eager to forgive and reconcile. Justice values mean nothing if they are not profoundly internalised by individuals and groups.

In making my argument, I turn to reformed theological resources. By presenting a reformed approach, I neither assert that reformed theology provides the only avenue to address the intricate web of moral issues at stake when it comes to social justice nor that reformed theology presents the solution to the complex moral issue of land. The intent, rather, is to present $a$ preliminary perspective from a particular theological vantage point about a highly complicated social issue that requires input from all sectors and groups in South Africa. My question is: Can reformed theology add an extra ingredient to the social justice values at our disposal? Could it perhaps contribute to recalibrate our disposition towards justice values in the South African debate? How would such a recalibration affect our understanding of human identity formation?

Three theological themes in reformed theology are, in my view, pertinent to the issue of embracive justice, namely its 
understanding of the dialectical tension that exists between Law and gospel, its presentation of Christ's sacrifice as an act of embrace to resolve a seemingly unsolvable impasse between the infinite God and finite human beings, and the importance of self-denial and cross-bearing as fundamental features of Christian identity formation.

The law-gospel theme in reformed theology closely juxtaposes God's justice with God's grace. Following Paul's letter to the Romans, the reformed tradition understands the law as a mirror of God's demand for justice and righteousness in the face of evil and $\sin$, and as a reminder of the severe and ultimate penalty of death for $\sin (\operatorname{Rm} 3: 19,20)$. The 1563 Heidelberg Catechism (HK 4, question 11) states it as follows:

God is indeed merciful, but also just; therefore his justice requires that sin which is committed against the most high majesty of God be also punished with extreme; that is with everlasting punishment of body and soul. (see Beeke \& Ferguson 1999:48)

The Westminster Larger Confession of 1648 (question 27) articulates the consequences of sin even more emphatically:

The fall brought upon mankind the loss of communion with God, His displeasure and curse, so as we are by nature children of wrath. (see Beeke \& Ferguson 1999:49)

The above citations may sound to some like overkill, but the theological intent must be kept in mind. The righteous demands of the Law compels us to reflect on our own misery and impurity (Inst. 2.8.3; HK 1, question 2). Indeed, we can exhibit no understanding of the unfathomable nature of God's grace if the Law does not open our eyes to the pervasive effects of $\sin$ on our lives and the utter misery in which we are engulfed. Without the glasses of the Law, we remain engulfed in 'blindness' (Inst. 2.2.24). The poignant issue at stake here is that reformed theology takes sin seriously. Human sin should not be glossed over and injustices cannot be left unanswered. God calls the perpetrator to account and demands 'full satisfaction' of the Law (HK 4, question 12).

The land issue in South Africa ought to serve as a vivid reminder of the systemic nature of sin. Yet, Gibson's survey (2009) makes the disturbing observation that white South Africans, in general, exhibit little interest in or knowledge of the historical events and discriminative legislation that led to black, mixed race and Asian communities being dispossessed of land. Collective amnesia is not a surprising reaction and, in fact, even quite common among communities whose members have been implicated in war crimes or crimes against humanity (see Volf 1996:131-140). Yet, such a response is not excusable, because it reveals a form of denial, a disassociation with reality, an unwillingness to carry the burden of history and a reluctance to face inconvenient truths head-on.

Justice requires that we deal honestly with the hard truths of history and that we search the darkness of our souls. Applied to the land issue, white communities ought to recognise that grave and indefensible injustices were committed against black, mixed race and Asian communities through discriminative land legislation that systemically impoverished generations of people. Denying the systemic impact of land injustices on many communities in South Africa or misusing economic arguments to preserve the status quo, not only amounts to denial, but actually perpetuates the injustices that have been committed. As long as the hard facts of history are not acknowledged, recognised and dealt with, generations of white communities will be haunted by the burden of history. Justice demands truth and repentance. We cannot be selective in what we forget and remember. Redemption is not possible as long as we deny inconvenient truths.

Yet, the opposite side of the coin is also true. Collective amnesia is inexcusable, but so is a populist sense of victimhood that preys on an inflated and often selective awareness of the historical injustices committed against me and my group. History teaches us that victims can easily become perpetrators when a persistent remembrance of the historical wrongs committed against them are nurtured and abused to mobilise them socially. To demand the righting of wrongs, committed against the self, is certainly legitimate, but to use people's pain for political gain is a form of cruel exploitation. The universal nature of sin ought to moderate our claims that we are victims. Paul aptly reminds us that Jew and non-Jew stand under the universal power of sin and we are all cursed by the Law of God that demands perfect righteousness (Rm 3:9-10). No person is just or can claim absolute innocence. We are all perpetrators who deserve God's wrath.

This brings us to the issue of embrace. Paul argues in Romans that the Law in itself does not liberate. Justice without embrace and truth without love does not redeem, but grows into a 'curse' that condemns and destroys (Rm 4:15). The Law needs the gospel to survive; it is a means to an end, not a goal in itself. Worshipping the Law can only result in an oppressive legalism. How vividly have we not experienced this in the land controversy? The High Level Panel Report notes that land restitution is hindered by conflicting claims and consistent legal strife:

These contribute to ethnic and tribal tension, and xenophobic attitudes, as communities form narratives for why they and not others, are entitled to large swathes of land. (Mothlanthe 2017:234)

The gospel's logic is governed by God's embracive acts in a hopeless situation; God making a new future possible when all seems lost due to sin and evil. Calvin (Inst. 2.12.1) spoke of the great exchange between the infinite God and mortal human beings, characterised by a cycle of descent and ascent. Through the incarnation of the Son, God descends to humanity in order to pay for our sins and to liberate us from our misery so that we can ascend with Christ through the Spirit to God. Here we encounter a kind of justice that the Reformers called iustitia aliena - God declares us free of guilt 
on the basis of Christ's propitiatory obedience. The embracive justice God enacts is no imaginary justice - it is real in that Christ truly suffered the penalty for our sins. Yet, it is also a justice characterised by a reconciliatory attitude that does not seek to destroy humanity, but to restore its relationship with God. Reconciliation is the orienting value behind God's justice - not fair due process or retribution - although these justice values are certainly at stake in the Christ event.

The incarnation of Christ constitutes an act of divine selflimitation for the sake of restored relations. God becomes human, Jesus takes on the form of a slave and carries the curse of the Law to make possible a new relationship and a new future between God and humanity. But the great exchange is not a purely unilateral act. It also entails that the faithful become slaves of Christ by accepting God's gift of grace in faith and enacting the example of Christ in their own lives (see Phlp 1:29). Christ becomes a slave in human form so that we can become slaves of Christ. Faith is, consequently, not a passive act, but requires that we actively embrace God's gift of grace. Stated differently: Faith requires a changed human identity.

Calvin (Inst. 3.1.1) famously identified meditation on the future life, cross bearing and self-denial as key features of the Christian life. The latter two Christian virtues are, in my view, especially pertinent to our discussion of the intricate connection between embracive justice and human identity. ${ }^{2}$ For Calvin (Inst. 3.7.5; Zachmann 2009:476), cross-bearing entails that we conform to the image of Christ by bearing afflictions patiently and exhibiting a willingness to suffer for the sake of righteousness, while self-denial requires that we repent before God, realise our shortcomings and use the divine gifts bestowed on us to serve the interests of our neighbours. Calvin and the reformed tradition essentially understand the Christian life and discipleship as consisting of a faithful embrace of God and fellow human beings. True Christian identity is hybrid and permeable in nature: open to self-correction, unselfish, caring, empathetic, peace loving, truthful and fair. Above all, it is willing to make sacrifices for the sake of the other.

Protestant liberalism has questioned the reformed faith's understanding of the gospel as atonement through satisfaction, justification through the imputation of God's righteousness to human beings in Christ, and its perceived obsession with altruism (cross-bearing and self-denial). They generally deem the notion that God demands satisfaction for the transgression of his Law as vindictive logic and construe the idea that one person can pay for the sins of another as compromising human autonomy. Moreover, some are concerned that the cultivation of overly altruistic attitudes can undermine individual rights discourse (see Vorster 2013:133-136). We cannot go into these objections at this time, except to say that

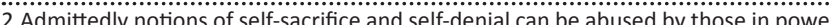
to cultivate 'unhealth' forms of altruism among the powerless so that they will stay silent in the face of exploitan silent in the face of exploitation. It needs to be noted that Calvin used these notion to encourage sacrifice for the sake of righteousness not at the expense of righteousness. Altruistic values are indeed important for social cohesion, but could become harmful if employed as a means to suspend justice values. the power of the reformed notion of reconciliation resides precisely in its logic that the historical impasse between God and human beings - brought about by the systemic nature of $\sin$ - can only be resolved through an iustitia aliena that transcends conventional notions of human justice. God does not follow conventional justice logic, but embraces us in a manner that circumvents human logic, undercuts human autonomy, surpasses due process and defies retributive logic to make a new beginning possible. The Christ event was a once-off and non-repeatable event executed by a God who himself is the norm of righteousness. Finite beings cannot execute justice in the exact same manner; neither can we be Christ. We can follow Christ and are called to do so, but only up to a point.

That said, reformed theology maintains that the Christ event has a lasting normative impact on our lives - not only as far as the relationship between the infinite God and finite beings is concerned - but also interhuman relationships. Our actions should shine forth the embracive spirit of the Christ event. While Christians can neither coerce faith nor force groups to accept God's Law and gospel or to follow Christ through cross bearing, they can make an effort to display a kind of embrace that breathes the spirit of the Christ event.

This brings me to the notion of embracive justice. What does embracive justice entail? How does it differ from the restorative justice approach that the Truth and Reconciliation Commission followed in the 1990's? Embracive justice recognises that a situation could evolve where cycles of past injustices have burdened a society with an impasse that cannot be resolved through ordinary means of justice. This impasse, I argue, can only be overcome through a generous spirit of embrace and an extraordinary act of self-sacrifice by perpetrators, victims and ordinary members of society. Embracive justice is not a formal kind of justice administered from 'above' by legal regimes, courts or tribunes; it requires spontaneous acts of self-sacrifice from below. Detractors may argue that embracive justice is simply another word for restorative justice. Restorative justice, after all, endorses similar kinds of reconciliatory values such as restoration of victims, rehabilitation of offenders and reconciliation between groups. I agree, but there is also a fundamental difference. Restorative justice is a formal approach utilised within criminal justice systems that contains a clearly defined distinction between victim and perpetrator as well as a clear definition of the crime that was committed. The approach I am propagating is focused on the intergenerational dynamics of transitional social contexts where the lines between victim and perpetrator are not that clear. Embracive justice is not concerned with fair procedure, but with attitude and just actions. Moreover, embracive justice does not limit itself to ideals of restoration, but it is directed at creating a future order where coming generations can live in a normal and stable environment devoid of the systemic effects of past injustices.

When it comes to the land debate, I believe that embrace and reconciliation should orient our disposition to justice. 
Justice, especially when it comes to intergenerational issues, should not, in the first place, be about due desert, but rehabilitation and the creation of a fair future order. Although due process is an important condition for fair treatment, we ought to recognise that overly extensive and technical processes of land restitution and redistribution could defeat justice in the name of justice. Ways ought to be found to cut red tape and to expedite land restitution and redistribution processes in the spirit of embrace. Secondly, embracive justice requires that groups refrain from collective amnesia about the past or the exaggerated sense of victimhood that underlies retributive logic. We should acknowledge that colonial land grabs were deeply unjust and that the unequal distribution of property rights in South Africa is morally unacceptable. Conversely, we should exhibit a spirit of forgiveness towards each other and accept that retributive logic could result in an unjust situation being replaced by an equally unjust scenario where the victims of the past become perpetrators of the future. Lastly, embracive justice is about more than simply the rehabilitation of the perpetrator or reconciliation between perpetrator and victim; it also asks for a spontaneous sacrifice with lasting effect from the side of everyone, but specifically those communities who benefited directly or indirectly from the Apartheid system. Such a sacrifice ought to be made in the spirit of self-denial and cross bearing for the sake of righteousness and the well-being of future generations. I do not propose a sacrifice that amounts to self-destruction, but I argue that a spontaneous collective sacrifice by specifically white communities in the spirit of self-denial could be an embracive gesture that de-escalate the land conflict in South Africa. Such a sacrifice could consist of the creation of trusts focused on the development and empowerment of black farmers; the establishment of compensation funds for damages caused by past land injustices; the availing of underutilised land for empowerment projects; and making farmworkers business partners in commercial farms. Many possibilities exist. The point is that embracive gestures are needed to resolve the impasse that South Africa faces. Legal instruments cannot do it on their own.

\section{Final remarks}

The South African land question will not be resolved as long as embrace does not orient our actions. Embracive justice recognises that justice is about more than fairness, due process, redress and due desert; it is also about creating a situation of reconciliation that helps to resolve conflicts in situations where historical injustices have created an impasse that is impossible to resolve through regular justice approaches. I understand embracive justice as a type of justice where the various parties are focused on creating a fair future order that serves the best interests of the broadest range of fellow citizens and that ensures that future generations can live in a society freed of the burden of history. Moreover, I argue that embracive justice requires more than merely changing our theoretical outlook on justice; it also demands the formation of group identities that are hybrid and permeable as well as willing to make some costly sacrifices for the sake of future generations. Drawing on the reformed tradition's emphasis on crossbearing and self-denial as Christian virtues, I suggest that permeable identities are characterised by a spirit of repentance, an openness to self-correct, a willingness to make sacrifices and forego some perceived entitlements for the sake of the common good, an embrace of the other, and a reconciliatory attitude. To summarise: Embracive justice constitutes an act from below that circumvents formal justice logic and enacts the Spirit of Christ.

\section{Acknowledgements Competing interests}

The author declares that he has no financial or personal relationship(s) which may have inappropriately influenced him in writing this article.

\section{References}

Atuahene, B., 2011, 'South Africa's land reform crisis: Eliminating the legacy of Apartheid', Foreign Affairs 90(4), 121-129.

Beeke, J.R. \& Ferguson, S.B., 1999, Reformed confessions harmonized: With an annotated bibliography of annotated doctrinal works, Baker Books, Grand Rapids, MI.

Beinart, W., Delius, P. \& Hay, M., 2017, Rights to land. A guide to tenure upgrading and restitution in South Africa, Jacanda Media, Johannesburg.

Calvin, J., 2008, Institutes of the Christian religion, transl. H. Beveridge, Hendrickson Publishers, Peabody, MA.

Choruma, A., 2017, 'How to defuse South Africa's ticking land time-bomb', New African (Nov), 32-33.

Constitution, see South Africa 1996.

Cousins, B. \& Scoones, I., 2010, 'Contested paradigms of 'viability' in redistributive land reform: Perspectives from southern Africa', The Journal of Peasant Studies 37(1), 31-66. https://doi.org/10.1080/03066150903498739

Gibson, J.L., 2009, Overcoming historical injustices. Land reconciliation in South Africa, Cambridge University Press, New York.

Inst., see Calvin 2008

Kepe, T. \& Hall, R., 2018, 'Land redistribution in South Africa: Towards decolonisation or recolonisation?', Politikon 45(1), 128-137. https://doi.org/10.1080/02589346. 2018.1418218

Mahlaka, R., 2018, Seven questions about expropriating land without compensation, viewed 01 March 2018, from https:www.moneyweb.co.za/news/south-africa/ seven-questions-on-expropriating-land-without-compensation

Merten, M., 2018, Parliament: Historic land expropriation agreement reached amid South Africa's changing politics, viewed 28 February 2018, from https:// dailymaverick.co.za/section/south-africa

Mothlanthe, K., 2017, Report of the High Level Panel on the assessment of key legislation and the acceleration of fundamental change, viewed 28 February 2018 from https://www.parliament.gov.za/storage/app/media/Pages/2017/october/High Level_Panel/HLP_Report/HLP_report.pdf

O'Laughlin, B., Bernstein, H., Cousins, B. \& Peters, E.E., 2013, 'Introduction: Agrarian change, rural poverty and land reform in South Africa since 1994', Journal of Agrarian Change 13(1), 1-15. https://doi.org/10.1111/joac.12010

Pienaar, J.M., 2015, 'Land reform embedded in the constitution: Legal contextualisation', Scriptura 114, 1-20. https://doi.org/10.7833/114-0-1116

South Africa, 1996, Constitution of the Republic of South Africa as adopted by the Constitutional Assembly on 8 May 1996 and as amended on 11 October 1996, Government Printers, Pretoria.

Van der Elst, H., 2017, 'Die wegbeweeg vanaf gematigdheid na 'n radikale grondverdelingsbenadering as transformasie prioriteit in Suid-Afrika', Tydskrif vir Geesteswetenskappe 57(4), 955-970.

Volf, M., 1996, Exclusion and embrace. A theological exploration of identity, otherness and reconciliation, Abingdon Press, Nashville, TN.

Vorster, J.M., 2006, 'The ethics of land restitution', Journal of Religious Ethics 34(4), 685-707. https://doi.org/10.1111/j.1467-9795.2006.00290.x

Vorster, N., 2013, 'The nature of Christ's atonement. A defense of penal substitution theory', in E. van der Borght \& P. van Geest (eds.), Strangers and pilgrims on earth, pp. 129-147, Brill, Leiden.

Zachmann, R.C., 2009, "'Deny yourself and take up the Cross": John Calvin on the Christian life', International Journal of Systematic Theology 11(34), 466-482. https://doi.org/10.1111/j.1468-2400.2009.00469.x 